\title{
Pengembangan Media Biblioedukasi Buku Cerita "Scars Make You Strong" untuk Meningkatkan Self-Esteem Anak di Pondok Tahfidz Quran LAZNAS Nurul Hayat Malang
}

\author{
Siti Fatimah Roba'ah*, M Ramli, Muslihati \\ Universitas Negeri Malang, Jl. Semarang No. 5 Malang, Jawa Timur, Indonesia \\ *Penulis korespondensi, Surel: fatimah.robaah.1juni@gmail.com
}

Paper received: 2-1-2021; revised: 23-1-2021; accepted: 30-1-2021

\begin{abstract}
This research aims to develop educational bibliographic media "Scars Make You Strong" to Increase Self-Esteem of children in Pondok Tahfidz Quran LAZNAS Nurul Hayat Malang. This study was developed to help facilitate counseling teachers in providing group guidance interventions using bibli education techniques. The scope of this research is the bibliographic media of the story book "Scars Make You Strong" to increase the self-esteem of the adolescent children. This study uses the model Research and Development (R\&D) developed by Borg and Gall (1983) with the following steps: data collection, planning, product development, testing (BK material expert \& media expert), revision of the results of expert testing and candidate testing users, revised trial results, and the final product. Expert testing and field testing of prospective users were analyzed using quantitative data analysis using the formula average (mean) and qualitative data analysis. The validity index of expert and prospective user tests shows high criteria and meets acceptability, namely usability, accuracy, convenience, and attractiveness, so that the product is feasible and can be given to prospective users of story books, namely children in the cottage, and guidebooks for use for counseling teachers / guidance teachers.
\end{abstract}

Keywords: media biblioeducation; story book "Scars Make You Strong; self-esteem; cottage children

\begin{abstract}
Abstrak
Penelitian ini bertujuan untuk mengembangkan media biblioedukasi Buku Cerita Bergambar "Scars Make You Strong" untuk Meningkatkan Self-Esteem anak di Pondok Tahfidz Quran LAZNAS Nurul Hayat Malang. Penelitian ini dikembangkan guna membantu memudahkan guru BK dalam pemberian intervensi bimbingan kelompok menggunakan teknik biblioedukasi. Ruang lingkup dalam penelitian ini adalah media biblioedukasi buku cerita "Scars Make You Strong" untuk meningkatkan self-esteem anak pondok. Penelitian ini menggunakan model Research and Development (R\&D) yang dikembangkan oleh Borg dan Gall (1983) dengan langkah : melakukan pengumpulan data, perencanaan, pengembangan produk, uji coba (ahli materi BK \& ahli media), revisi dari hasil uji ahli dan uji calon pengguna, revisi hasil uji coba, serta produk akhir. Uji ahli dan uji lapangan calon pengguna dianalisis menggunakan analisis data kuantitatif menggunakan rumus rata-rata (mean) dan analisis data kualitatif. Indeks validitas uji ahli dan calon pengguna menunjukkan kriteria yang tinggi dan memenuhi akseptabilitas yakni kegunaan, ketepatan, kemudahan, dan kemenarikan, sehingga produk layak dan dapat diberikan pada calon pengguna buku cerita yakni anak di pondok, dan buku panduan penggunaannya untuk guru BK/guru pembina.
\end{abstract}

Kata kunci: media biblioedukasi; buku cerita "Scars Make You Strong; self-esteem; anak pondok

\section{Pendahuluan}

Setiap anak berharap memiliki sebuah keluarga dengan orang tua yang lengkap dan harmonis, mendapatkan pendidikan yang layak sebagaimana mestinya, dapat mengembangkan potensi diri, mengembangkan karakter kepribadian yang berintegritas, serta menjadi sosok yang selama ini dicita-citakannya. Tetapi tidak semua anak bisa mendapatkan 
kehidupan yang layak atau mengalami proses perkembangan diri yang lebih baik. Banyak dijumpai fenomena perkembangan pribadi anak yang tidak tinggal bersama dengan orangtua, berbeda dengan yang mendapat asuhan dan kasih sayang langsung dari orangtua. Anak yang berbeda tempat tinggal dengan orangtuanya akan membawa pengaruh pada perkembangan anak secara umum (Singgih dan Yulia, 1983: 154).

Salah satu fenomena yang sering dijumpai adalah banyaknya anak yang harus berpisah tinggal dengan orangtuanya lantaran faktor masalah dalam keluarga. Pada beberapa kasus, Anak harus dibawa ke institusi seperti panti asuhan maupun yayasan sosial, dengan ragam alasan seperti kematian orang tua, ditinggalkan oleh keluarga, kondisi ekonomi, ataupun perceraian yang terjadi dalam keluarga (Jacobi, 2009). Institut seperti panti asuhan maupun yayasan sosial berusaha untuk memperjuangkan hak-hak anak yang kurang beruntung untuk mendapatkan hidup yang layak. Borualogo (2004) mengemukakan bahwa panti asuhan/ yayasan sosial berperan sebagai pengganti keluarga dalam memenuhi kebutuhan anak dalam proses perkembangannya.

Perkembangan anak dipengaruhi oleh pengasuhan orang tua (Santrock, 2003). Perkembangan psikologis anak yang tidak tinggal bersama orang tua, seperti di panti asuhan, pondok pesantren, asrama, atau lembaga yayasan sosial lainnya berbeda dengan perkembangan anak yang diasuh langsung oleh kedua orang tua. Sedangkan anak yang tinggal di yayasan sosial tidak mendapatkan pengasuhan langsung dari orang tua, tetapi dari pengasuh dan teman-teman yang tinggal di yayasan tersebut. Anak yang tinggal tidak bersama dengan orang tua akan mengalami berbagai bentuk pergolakan emosi anak yang membawa pada selfesteem rendah pada diri anak (Marwati dkk,2016).

Hasil penelitian tentang kondisi psikologis anak-anak yang tinggal di panti asuhan atau yayasan sosial, seperti yang dikemukakan oleh Hartini (2000) menunjukkan gambaran kebutuhan psikologis anak panti asuhan cenderung memiliki kepribadian yang inferior, pasif, apatis, menarik diri, mudah putus asa, serta penuh dengan ketakutan dan kecemasan. Sehingga anak panti asuhan akan sulit menjalin hubungan sosial dengan orang lain. Disamping itu mereka menunjukkan perilaku yang negatif takut melakukan kontak dengan orang lain, lebih suka sendirian, dan menunjukkan sikap egosentrisme. Jurnal Konseling dan Pendidikan menyatakan bahwa $40 \%$ anak yang tinggal di panti asuhan memiliki self-esteem rendah (Hermivia, 2014).

Diungkapkan pula oleh Santrock (2003) yakni masalah yang muncul menjadi lebih meningkat, ketika tingkat harga diri (self-esteem) remaja yang rendah, berhubungan dengan proses perpindahan sekolah atau keluarga yang sulit dan kejadian yang membuat remaja tertekan. Coopersmith (1967) menjelaskan self-esteem (harga diri) adalah hasil evaluasi individu terhadap diri sendiri yang diekspresikan dalam sikap terhadap diri sendiri. Evaluasi ini menyatakan suatu sikap penerimaan atau penolakan dan menunjukkan seberapa besar individu percaya bahwa dirinya mampu, berarti, berhasil, berharga, menurut standar dan nilai pribadinya. Anak yang memiliki self-esteem positif akan melakukan berbagai aktivitas dengan kepercayaan diri yang tinggi yang didasari oleh alasan alasan yang rasional. Dan sebaliknya apabila anak memiliki self-esteem yang rendah maka setiap tindakannya akan didorong oleh kepercayaan diri yang rendah. Hal tersebut menyebabkan anak mengalami kesulitan untuk berprestasi dalam bidang apapun. 
Sasaran dalam penelitian ini adalah LAZNAS (Lembaga Amil Zakat Nasional) Nurul Hayat. Hasil studi pendahuluan yang dilakukan peneliti sebagai bahan asesmen kebutuhan, dengan menggunakan berupa instrumen self-esteem yang dikembangkan oleh Coopersmith yakni Coopersmith sel-Esteem Inventory (CSEI, 1967) yang diadaptasi oleh J.T Tobby Loekmono (2011) lalu diadopsi oleh peneliti melalui Kusmartini (2015) yang telah teruji validitas dan reliabilitasnya, menyatakan bahwa dari total 35 anak di LAZNAS Nurul Hayat Malang yang memiliki self-esteem rendah sebanyak 45.78\% (16 anak), self esteem sedang sebanyak $45.78 \%$ (16 anak), dan self-esteem tinggi sebanyak 8,59\% (3 anak). Sedikitnya anak yang memiliki selfesteem tinggi mengindikasikan perlunya pemberian perlakuan khusus supaya anak-anak yang tinggal di LAZNAS Nurul Hayat Malang ini dapat meningkatkan self-esteem di dalam dirinya.

Di berbagai pendekatan bimbingan dan konseling ada banyak teknik dalam bimbingan untuk meningkatkan self-esteem anak, salah satunya adalah dengan menggunakan teknik biblioedukasi yang mana didefinisikan sebagai penggunaan buku dalam proses terapiutik. Biblioedukasi dapat diterapkan dalam bentuk audio maupun visual, seperti recorder, buku, video, film dan sebagainya (Ekowati 2015). Dalam era pembelajaran yang semakin inovatif saat ini, kehadiran media bimbingan merupakan sesuatu yang bisa dikatakan wajib. Dengan latar belakang tersebut penelitian ini bermuara pada pengembangan produk yang nantinya dapat digunakan sebagai media dalam meningkatkan self-esteem anak. Produk yang dikembangkan adalah buku cerita bergambar dengan judul "Scars Make You Strong" sebagai media biblioedukasi dalam layanan bimbingan kelompok untuk meningkatkan self-esteem anak di pondok. Mengapa tidak menggunakan jenis media yang lain, dikarenakan berdasarkan studi pendahuluan yang dilakukan mendapati bahwa minat baca anak-anak di pesantren Nurul Hayat sangat tinggi karena mereka menjadikan buku sebagai kegiatan menghibur di sela-sela kegiatan pondok, dan juga tidak diperbolehkannya anak di pesantren membawa alat elektronik seperti HP, Laptop, dan lain lain, menjadikan buku sebagai satu-satunya sarana media informasi maupun media hiburan yang bisa mereka nikmati. Dengan media buku cerita, yang disertai gambar ilustrasi, sebagai teknik biblioedukasi, akan dapat menghibur anak-anak di Pesantren seraya belajar dan memotivasi untuk menjadi pribadi yang lebih baik dan sebagai sarana meningkatkan self-esteem dalam diri. Luaran yang diharapkan dengan adanya penelitian ini yakni terciptanya suatu produk media untuk mempermudah anak dalam mengembangkan self-esteemnya.

\section{Metode}

Rancangan penelitian yang digunakan dalam penelitian ini yaitu penelitian dan pengembangan yang biasanya dikenal dengan istilah Research and Development ( $\mathrm{R}$ \& $\mathrm{D}$ ). Rancangan penelitian ini diadaptasi dari Borg \& Gall. Menurut Borg \& Gall (1983) langkahlangkah dalam penelitian dan pengembangan terdiri dari sepuluh langkah. Dalam penelitian dan pengembangan ini diselesaikan sampai 5 langkah yaitu 1) studi pendahuluan, 2) perencanaan penelitian, 3) pengembangan produk awal, 4) uji coba lapangan awal, 5) revisi hasil uji coba, 6) produk akhir.

Uji coba lapangan awal dilakukan untuk memperoleh data mengenai produk yang akan dikembangkan. Jenis data dalam penelitian berupa kuantitatif dan kualitatif. Data kuantitatif diperoleh dari penilaian ahli dalam angket. Instrumen penelitian yang digunakan dalam penelitian ini berupa angket dengan skala penilaian 1-4 yang mana angka 1 menunjukkan produk tidak layak dan 4 menunjukkan produk sangat layak. Pengumpulan data bermaksud 
untuk digunakan sebagai acuan kelayakan dan keberterimaan produk yang akan diberikan kepada calon pengguna yaitu konselor sekolah

Analisis data kuantitatif yang telah diperoleh kemudian dihitung tingkat kevalidannya dengan rumus pedoman tingkat kelayakan produk berdasarkan rumus Arikunto (2006) sebagai berikut:

$$
P=\frac{x}{x 1} \times 100 \%
$$

Keterangan :

$\mathrm{P} \quad=$ persentase yang dicari

$\mathrm{X}=$ jawaban responden dalam 1 item

$\mathrm{X}_{1}=$ jumlah jawaban responden dalam 1 item

$100 \%$ = bilangan konstan

Terdapat empat kategori kualifikasi, yaitu (1) Hasil produk pengembangan berupa buku panduan tergolong kualifikasi valid sehingga layak untuk digunakan apabila tingkat persentase 85\%-100\%, (2) Hasil produk pengembangan berupa buku panduan tergolong kualifikasi cukup valid sehingga cukup layak untuk digunakan apabila tingkat persentase 60\%-79\%, (3) Hasil produk pengembangan berupa buku panduan tergolong kualifikasi kurang valid sehingga kurang layak untuk digunakan apabila tingkat persentase 40\%-59\%, (4) Hasil produk pengembangan berupa buku panduan tergolong kualifikasi tidak valid sehingga tidak layak untuk digunakan apabila tingkat persentase 0\%-39\%.

Tabel 1. Kriteria kelayakan produk

\begin{tabular}{|c|c|c|c|}
\hline \multicolumn{3}{|c|}{ Hasil Uji } & \multirow[t]{2}{*}{ Kualifikasi } \\
\hline Kategori & Persentase & Kriteria Keberhasilan & \\
\hline 1 & $85 \%-100 \%$ & Layak & Valid/ Tidak Revisi \\
\hline 2 & $60 \%-79 \%$ & Cukup Layak & Cukup Valid/ Tidak Revisi \\
\hline 3 & $40 \%-59 \%$ & Kurang Layak & Kurang Valid/ Revisi Sebagian \\
\hline 4 & $0 \%-39 \%$ & Tidak Layak & Tidak Valid/ Revisi Keseluruhan \\
\hline
\end{tabular}

\section{Hasil dan Pembahasan}

\subsection{Hasil}

Produk akhir dari penelitian dan pengembangan ini yakni produk berupa buku cerita bergambar "Scars Make You Strong" dengan disertai buku panduan pelaksanaannya melalui bimbingan kelompok untuk meningkatkan self-esteem anak di Pondok Pesantren Tahfidz Quran LAZNAS Nurul Hayat Malang. Produk yang dihasilkan ditujukan kepada anak di pondok dan guru BK/ guru pembina di pondok. Dalam buku cerita memuat empat bagian cerita bersambung, sedangkan dalam buku panduan memuat tiga bagian. Bagian pertama adalah pendahuluan yang menjabarkan tentang latar belakang, tujuan, dan sasaran pengguna produk. Bagian dua adalah petunjuk pelaksanaan yang menjabarkan tentang deskripsi produk, prosedur pelaksanaan layanan bimbingan kelompok menggunakan media biblioedukasi buku cerita "Scars Make You Strong", serta RPLBK untuk empat kali pertemuan bimbingan kelompok. Bagian tiga adalah penutup, yang dilanjutkan dengan lampiran-lampiran. Berikut hasil penilaian dari uji ahli dan uji calon pengguna: 
Tabel 2. Hasil penilaian pengembangan panduan oleh ahli (ahli materi dan ahli media)

\begin{tabular}{llclc}
\hline No & $\begin{array}{l}\text { Kriteria Penilaian } \\
\text { Ahli Materi }\end{array}$ & $\begin{array}{l}\text { Hasil Rata-Rata } \\
\text { Penilaian }\end{array}$ & $\begin{array}{l}\text { Kriteria Penilaian } \\
\text { Ahli Media }\end{array}$ & $\begin{array}{c}\text { Hasil Rata-Rata } \\
\text { Penilaian }\end{array}$ \\
\hline 1 & Aspek Ketepatan & $75 \%$ & Aspek Ketepatan & $87 \%$ \\
2 & Aspek Kegunaan & $91 \%$ & Aspek Kegunaan & $100 \%$ \\
3 & Aspek Kemudahan & $82 \%$ & Aspek Kemudahan & $87 \%$ \\
4 & Aspek Kemenarikan & $75 \%$ & Aspek Kemenarikan & $93 \%$ \\
& Rata-Rata & $83 \%$ & Rata-Rata & $93 \%$ \\
\hline
\end{tabular}

Dalam penilaian uji ahli materi terdapat beberapa saran atau masukan, diantaranya adalah perlunya memperhatikan sistematika penulisan sesuai dengan PPKI dan konsistensi dalam penggunaan istilah istilah dalam buku panduan. Selain itu perlunya dikaji ulang mengenai aspek aspek ketepatan langkah-langkah penggunaan teknik media biblioedukasi. Ahli materi juga menyarankan untuk meningkatkan kecerahan pada desain gambar buku cerita agar tidak terlalu terkesan 'dark' untuk anak usia SMP, dan memperhatikan ukuran tulisan dan komposa gambar sesuai dengan karakteristik peserta didik di pondok apakah gemar membaca atau tidaknya, sebagai upaya peningkatan produk buku cerita yang dikembangkan untuk meningkatkan self-esteem.

Menurut pendapat ahli media, secara umum media buku cerita dan buku panduan yang dikembangkan menarik baik dari ide maupun desain media. Pemilihan warna dalam desain juga cukup menarik. Namun terdapat beberapa hal perlu diperhatikan antara lain yakni; jenis font yang dipakai dalam buku panduan pada halaman 65 untuk teks panjang sebaiknya gunakan Arial atau Calibri saja. Frame dalam RPLBK buku panduan mengenai materi layanan boleh untuk tidak dipakai karena kontennya sudah berupa tabel. Keterbacaan font pada buku cerita halaman 31 masih kurang, dan sebaiknya dalam pemilihan jenis kertas pada buku cerita untuk dikurangi ketajaman pada sudut-sudut agar tidak terlalu lancip (lebih aman).

Tabel 3. Hasil penilaian pengembangan panduan oleh calon pengguna (konselor)

\begin{tabular}{clc}
\hline No & Kriteria Penilaian Ahli Materi & Hasil Rata-Rata Penilaian \\
\hline 1 & Aspek Ketepatan & $97,5 \%$ \\
2 & Aspek Kegunaan & $97,5 \%$ \\
3 & Aspek Kemudahan & $91 \%$ \\
4 & Aspek Kemenarikan & $93,5 \%$ \\
& Rata-Rata & $94,87 \%$ \\
\hline
\end{tabular}

Menurut pendapat calon pengguna, akan lebih efektif apabila diadakan langsung penelitian mengenai keefektifan (eksperimen) buku cerita bergambar dan mengadakan layanan bimbingan kelompok menggunakan teknik biblioedukasi dengan buku cerita "Scars Make You Strong" tersebut. Namun karena kendala pandemi, pertemuan yang melibatkan banyak orang secara langsung menjadi tidak relavan dengan produk yang dikembangkan. Namun secara keseluruhan buku cerita ini layak digunakan untuk meningkatkan self-esteem siswa setelah adanya perbaikan pada produk. 


\subsection{Pembahasan}

Produk akhir penelitian ini yakni berupa media biblioedukasi berupa buku cerita bergambar "Scars Make You Strong" untuk meningkatkan self-esteem anak di Pondok Pesantren Tahfidz Quran LAZNAS Nurul Hayat Malang. Temuan penelitian pengembangan ini sesuai dengan penelitian Mugiharto (2015) dengan judul Pengembangan Buku Cerita Bergambar Tentang Kehidupan Sehari-hari untuk Pembelajaran Membaca Bahasa Asing Siswa kelas XI, yang membuktikan bahwa peserta didik lebih mau belajar menggunakan media daripada hanya ceramah saja. Hal ini memiliki relevansi dengan pendapat Russel (dalam Indaryanti, Hartono, dan Aisyah, 2008) pembelajaran dengan media menyajikan kondisikondisi belajar yang optimal bagi masing-masing individu. Dengan tercapainya tujuan pendidikan media dapat digunakan secara efektif dan efisien (Sudjana dan Rivai, 2001).

Model penelitian pengembangan in mengadaptasi model pengembangan Borg and Gall. Secara teoritis, model pengembangan Borg and Gall (1983) terdiri dari sepuluh langkah. Pada penelitian ini disesuaikan dengan kebutuhan penelitian sehingga diselesaikan sampai 6 langkah yaitu sampai pada revisi hasil uji coba, dan produk akhir. Desain uji validasi produk menurut Committee (1994) terdapat empat aspek kriteria akseptabilitas. Berdasarkan hasil data uji validasi akseptabilitas oleh ahli materi dan media serta uji calon pengguna, produk ini telah memenuhi kriteria akseptabilitas yang terdiri dari aspek kebermanfaatan, ketepatan, kemudahan, dan kemenarikan.

Dalam buku cerita terdapat empat bagian cerita bersambung (cerbung), yang mana setiap cerbung akan digunakan dalam pertemuan layanan bimbingan kelompok. Layanan bimbingan kelompok dilakukan selama empat kali pertemuan. Pada pertemuan pertama, cerita bagian 1 mengarah pada pengenalan tentang definisi self-esteem. Pertemuan kedua, cerita bagian 2 mengarah pada pengenalan dan peningkatan self-esteem dalam diri melalui aspek self-esteem yang pertama yakni keberhasilan diri. Pertemuan ketiga, cerita bagian 3 mengarah pada peningkatan self-esteem melalui aspek self-esteem yang kedua yakni nilai dan aspirasi. Pertemuan keempat, cerita bagian 4 mengarah pada peningkatan self-esteem pada aspek pertahanan diri. Pada buku cerita, selain berisikan empat bagian cerita, pada beberapa halaman akhir cerita juga terdapat definisi singkat mengenai self-esteem serta berbagai langkah-langkah sederhana untuk meningkatkan self-esteem dalam diri, quotes penyemangat, lembar komitmen, serta lembar cita-cita sebagai reinforcement anak di pondok untuk lebih bersemangat dalam meningkatkan self-esteem dalam dirinya.

Produk buku cerita juga diiringi dengan pembuatan produk buku panduan penggunaannya, yakni melalui layanan bimbingan kelompok dengan teknik biblioedukasi untuk meningkatkan self-esteem anak di pondok. Pada buku panduan terdapat tiga bagian. Bagian pertama adalah pendahuluan yang menjabarkan tentang latar belakang, tujuan, dan sasaran pengguna produk. Bagian dua adalah petunjuk penggunaan produk yang menjabarkan tentang deskripsi produk, prosedur pelaksanaan bimbingan kelompok dengan menggunakan teknik biblioedukasi buku cerita "Scars Make You Strong", serta rancangan pelaksanaan layanan bimbingan dan konseling (RPLBK). Bagian tiga berisikan penutup, yang diiringi dengan daftar pustaka serta lampiran-lampiran.

Coopersmith (1967) menjelaskan self-esteem (harga diri) adalah hasil evaluasi individu terhadap diri sendiri yang diekspresikan dalam sikap terhadap diri sendiri. Evaluasi ini menyatakan suatu sikap penerimaan atau penolakan dan menunjukkan seberapa besar 
individu percaya bahwa dirinya mampu, berarti, berhasil, berharga, menurut standar dan nilai pribadinya. Menurut Arjan dkk (2006) self-esteem adalah konsep diri yang berhubungan dengan prestasi akademik, kemampuan sosial, dan psikopatologi anak dan remaja. Melalui buku cerita yang didesain sedemikian rupa untuk memberikan informasi awal mengenai konsep bersosial, akademis, serta berbagai masalah yang menyangkut kesehatan mental seorang anak, buku cerita "Scars Make You Strong" dapat berfungsi sebagai media preventif serta pemeliharaan self-esteem yang positif. Konselor dapat menggunakan buku cerita tersebut dan buku panduan penggunaan media biblioedukasi buku cerita dalam memberikan layanan bimbingan kelompok dengan tujuan meningkatkan self-esteem anak. Menurut Pehrsson \& McMillen (dalam Hariyadi dkk, 2004: 99) bibliokonseling adalah membaca dan mendiskusikan buku-buku tentang situasi yang mirip dengan situasi apa yang sedang dialami oleh-anak-anak. Demikian pula buku cerita "Scars Make You Strong" yang alur ceritanya dapat direfleksikan dengan kehidupan sosial peserta didik di pondok, sebagai media untuk peserta didik memperoleh informasi dan menambah wawasan tentang pentingnya self-esteem yang tinggi dalam pribadi peserta didik.

Produk buku cerita "Scars make You Strong" yang dikembangkan sudah tervalidasi oleh satu orang ahli materi dan satu orang ahli media yang merupakan langkah keempat penelitian dan pengembangan Borg \& Gall (1983). Hasil penilaian uji ahli materi didapatkan persentase rata-rata yaitu $83 \%$ sehingga produk yang dikembangkan dapat dikatakan cukup layak digunakan, namun perlu dilakukan revisi pada beberapa bagian untuk kesempurnaan isi. Pada penilaian uji ahli media didapatkan persentase rata-rata 93\% sehingga produk dapat dikatakan layak digunakan, namun perlu melakukan revisi pada beberapa bagian untuk kesempurnaan tata letak guna kerapian media. Sedangkan pada uji calon pengguna (peserta didik di pondok dan guru Bk/ pembina) didapatkan persentase rata-rata 94,87\%, dengan demikian media ini layak untuk dijadikan panduan. Setelah melalui revisi tahap akhir, buku ini dapat disimpulkan layak untuk digunakan sebagai media biblioedukasi pemberian intervensi untuk meningkatkan self-esteem anak di pondok.

Pada tahap revisi setelah dilakukan uji ahli (materi dan media), dilakukan penilaian analisis kuantitatif uji ahli dan calon pengguna (konselor) kemudian dilakukan perbaikan sesuai dengan saran yang telah diberikan. Setelah adanya perbaikan, media biblioedukasi buku cerita "Scars Make You Strong" ini dapat digunakan guru BK/ pembina untuk meningkatkan self-esteem anak di Pondok Nurul Hayat. Hasil akhir berupa buku panduan yang dicetak menggunakan kertas ukuran A4 dengan jilid Hard Cover menggunakan kertas art paper 150 gsm dengan sampul menggunakan kertas art carton 260 gsm. Pada sampul depan background berupa gambar sekawanan Troll sebagai karakter tokoh dalam cerita. Pada bagian tengah atas diletakkan judul "Scars Make You Strong". Cover belakang diberikan sinopsis cerita tentang petualangan Ellysia, tokoh utama, dalam mengatasi masalah dalam hidupnya. Pada buku panduan pelaksanaan bimbingan kelompok, dicetak dengan menggunakan kertas HVS ukuran A4, dengan judul "Buku Panduan Bimbingan Kelompok" dengan sub judul di bawahnya yakni "Penggunaan Media Biblioedukasi Buku Cerita Bergambar 'Scars Make You Strong' untuk Meningkatkan Self-Esteem Anak di Pondok Pesantren Tahfidz Quran LAZNAS Nurul Hayat Malang". bagian bawahnya bertuliskan identitas peneliti, logo UM beserta informasi jurusan, fakultas, dan universitas. 


\section{Simpulan}

Produk yang dikembangkan dalam penelitian pengembangan ini adalah Media Biblioedukasi Buku Cerita "Scars Make You Strong" untuk Meningkatkan Self-Esteem anak pondok. Produk ini telah memenuhi kriteria akseptabilitas yang terdiri dari aspek kegunaan, ketepatan, kemudahan dan kemenarikan yang telah diuji oleh ahli dan calon pengguna. Saran dari adanya penelitian ini yakni; 1) bagi konselor, konselor selain mempelajari dan memahami prosedur secara detail agar tujuan dapat terpenuhi dengan optimal, hendaknya konselor juga melakukan tindakan diseminasi produk pengembangan media ini, yakni dengan kegiatan mensosialisasikan dan menyebarluaskan hasil produk untuk kegiatan pengembangan media lebih lanjut 2) bagi peneliti selanjutnya, pengembangan panduan ini hanya sampai pada tahap uji ahli dan calon pengguna, sehingga dapat dilanjutkan oleh peneliti selanjutnya dengan menggunakan penelitian kuantitatif eksperimen untuk mengetahui penerapan media bibliodukasi buku cerita "Scars Make You Strong" untuk meningkatkan self-esteem anak pondok.

\section{Daftar Rujukan}

Borg, W.R. \& Gall, M.D. Gall. (1983). Educational Research: An Introduction Fifth Edition. New York: Longman.

Borualogo, I. S. (2004). Hubungan antara persepsi tentang fgur attchment dengan self esteem remaja panti asuhan muhammadiyah. Jurnal Psikologi, 13, 29-49.

Committee, J. (1991). Standart For Evaluations Of Educational Program, Projects, And Materials.

Coopersmith, S. (1967). Antecedents of Self Esteem. San Fransisco: W.H. Freeman and Company.

Ekowati, D. (2015). Effective bibliotheraphy untuk meningkatkan self-esteem pada anak slow learner di sd inklusi, PhD Proposal, 1, pp, 1-25.

Hartini, N. (2001). Deskripsi Kebutuhan Psikologi Pada Anak Panti Asuhan. Insan Media Psikologi, 3(2), 109118.

Olva, H., Ibrahim, Y., \& Marjohan, M. (2014). Hubungan self-esteem dengan motivasi belajar remaja panti asuhan 'Aisyiyah Daerah Cabang Lubuk Bagalung Padang. Jurnal Konseling Dan Pendidikan, 2(2), 14-18.

Indaryanti, I., Hartono, Y., \& Aisyah, N. (2008). Pengembangan modul pembelajaran individual dalam mata pelajaran Matematika di Kelas XI SMA Negeri 1 Palembang. Jurnal Pendidikan Matematika, 2(2), 35-44.

Jacobi, J. (2009). Between charity and education: orphans and orphanages in early modern times. Paedagogica Historica, 45(1-2), 51-66.

Marwati, E., Prihartanti, N., \& Hertinjung, W. S. (2016). Pelatihan berpikir optimis untuk meningkatkan harga diri pada remaja di panti asuhan. Indigenous: Jurnal Ilmiah Psikologi, 1(1), 23-31.

Mugiharto, M. M. (2015). Pengembangan Buku Cerita Bergambar tentang Kehidupan Sehari-hari untuk Pembelajaran Membaca Siswa kelas XI. Skripsi.

Santrock, J. W. (2003). Adolescence Perkembangan Remaja.

Gunarsa, S. D. (2008). Psikologi perkembangan anak dan remaja. BPK Gunung Mulia. 